\title{
Sobre la corrosión de armaduras de hormigón en presencia de cloruros
}

\section{On the corrosion of reinforcing steels in concrete in the presence of chlorides}

ANDRE RAHARINAIVO (LCPC) y JEAN-MARIE R. GENIN (Universidad de Nancy I)

\section{RESUMEN}

Este estudio pretende dar a ciertos resultados empíricos, una justificación científica en el campo de la corrosión de los aceros, en un hormigón que contenga cloruros.

En primer lugar, se pone de manifiesto que los productos de corrosión sobre los aceros tienen estructuras y naturalezas diferentes, en función de que el contenido de cloruro sea inferior o superior a un valor característico.

En segundo lugar, se puede describir la penetración de los cloruros en el hormigón por una sencilla ley de difusión de Fick, en los casos más frecuentes. Cuando el cemento contiene una elevada proporción de aluminato tricálcico, y el hormigón poca porosidad, no se aplica la ley de Fick.

\section{SUMMARY}

The purpose of this study is to give a scientific justification to some empirical results, in steel corrosion field, from concrete containing chlorides.

First, it appears that corrosion products on the stee/s, have different structures and natures in function of the chloride content would be inferior or superior to a characteristic value.

Second, the penetration of the chlorides in the concrete can be described by a simple Fick's diffusion law in the most frecuent cases. When cement has a high proportion of tricalcium aluminates and the concrete a small porosity, Fick's law cannot be applied.

\section{GENERALIDADES}

\subsection{Los cloruros en los hormigones}

Podemos encontrar cloruros en los hormigones, bien sea porque han sido introducidos intencionadamente para acelerar el fraguado, o porque proceden del medio ambiente que rodea las estructuras de hormigón. Este estudio trata principalmente de cloruros de origen externo que pueden introducirse en el hormigón hasta entrar en contacto con las armaduras.

Trabajos y observaciones de numerosos autores muestran que los cloruros pueden reaccionar con el aluminato tricálcico, que es un constituyente del cemento Portland, para formar un cloroaluminato. Sin embargo, esta reacción no es total y pueden quedar iones, en estado libre, en el agua de los poros del cemento endurecido.

\subsection{La corrosión de las armaduras}

Los aceros de las armaduras de hormigón

\section{SCOPE}

\subsection{Chlorides in concretes}

Chlorides can be found in concretes either because they have been wilfully added for hastening the cement hardening, or because they have come from the medium surrounding the concrete structures. In this investigation, it mainly deals with chlorides coming from the environment, which can enter the concrete down to the reinforcing steel level.

The works and observations carried out by numerous authors (1) have shown that chlorides can react with tricalcium aluminate, which is one of the Portland cement constituents, yielding chloroaluminate. However, this reaction is not complete and chloride ions can be, in a free state, in the intersticial water of the hardened cement.

\subsection{Reinforcing steel corrosion}

Reinforcing steels in concrete can undergo 
pueden experimentar formas diversas de corrosión que, en temperaturas usuales del orden de $20^{\circ} \mathrm{C}$, son de tipo electroquímico. Este estudio no considera la corrosión fisurante de los aceros de alta resistencia sometidos a una tracción para el pretensado del hormigón.

La corrosión de las armaduras conlleva, esquemáticamente, dos etapas. Durante la primera fase se desarrollan simultáneamente dos reacciones: en determinadas zonas, el metal ( $\mathrm{Fe}$ ) se disuelve, mientras que en otros puntos se produce una reacción catódica, por ejemplo, de los iones hidroxilos $\left(\mathrm{OH}^{-}\right)$si el contenido de oxígeno es suficientemente elevado en el agua intersticial.

Durante la segunda fase del proceso de corrosión, el ion metálico $\left(\mathrm{Fe}^{++}\right)$disuelto, reacciona con otros aniones del agua para formar un precipitado que cubre el acero. Las observaciones muestran que, si el hormigón está suficientemente sano, es decir, si su pH se mantiene elevado $(\mathrm{pH}>11)$ y si no está contaminado por sustancias tales como cloruros, el producto de recubrimiento del acero es suficientemente estanco como para que el agua no pueda alcanzar la superficie metálica. Así pues, es corriente afirmar que la alcalinidad del hormigón protege los aceros.

En presencia de cloruros, el producto de recubrimiento podría no ser estanco; de esta forma los aceros se corroen por disolución visible. Está admitido que la corrosión aparece si el contenido de cloruro $\left|\mathrm{Cl}^{-}\right|$rebasa cierto umbral que depende del pH del hormigón. En general, la corrosión es importante si, en el hormigón, a nivel de las armaduras: various types of corrosions which are basically electrochemical, at the usual temperature about $20^{\circ} \mathrm{C}$. This investigation does not take into account the cracking stress corrosion of high strength steels tensioned for prestressing concrete.

The steel corrosion includes schematically two stages. In the first stage, two reactions simultaneously occur: in some places, the metal $(\mathrm{Fe})$ is dissolved while at other places a so-called cathodic reaction occurs, yielding, for example, hydroxyl $\left(\mathrm{OH}^{-}\right)$ions, if the oxygen content is high enough in the intersticial water.

In the second stage of the corrosion process, the metal dissolved ion $\left(\mathrm{Fe}^{++}\right)$reacts with other ions (anions) in the water for giving a precipitate which covers the steel surface. Observations have shown that if the concrete is sound, i.e. if its $\mathrm{pH}$ remains high $(\mathrm{pH}>11)$ and if it is not polluted by agents such as chlorides the covering product is tight enough for preventing the water to rech the metal surface. So, it is usual to say that the concrete alkalinity is protecting steels.

When chlorides are present, the covering product can be untight, the steels are corroded with a visible dissolution. It is agreed that corrosion occurs if the chloride content $[\mathrm{Cl}]$ is higher than a threshold which depends on the concrete $\mathrm{pH}$. As a rule, corrosion is of importance if, in the concrete, at the reinforcing steel level, $[\mathrm{Cl}] \geq 6\left[\mathrm{OH}^{-}\right.$:

\section{$\left|\mathrm{Cl}^{-}\right| \geq 0,6\left|\mathrm{OH}^{-}\right|$}

\subsection{Finalidad del estudio}

Diversos autores han publicado un buen número de trabajos sobre la corrosión de las armaduras de hormigón en medios que contienen cloruros. Nuestro propósito es dar a ciertos resultados empíricos una justificación científica.

Los dos puntos que se abordan son los siguientes: en primer lugar el contenido de cloruro en el hormigón a nivel de las armaduras depende de una ley de difusión. La ley más utilizada es la de Fick, que no da importancia a las reacciones entre los cloruros y el aluminato tricálcico. Sin embargo la experiencia nos dice que esta ley se aplica con mucha frecuencia. Este estudio especifica los casos en los que se puede no tener en cuenta las reacciones químicas.

\subsection{Object of the investigation}

Numerous investigations have already published by various authors on the steel corrosion in concrete located in a chloride-containing medium. The object of this study is to give a scientific justification to some empirical results.

Two items have been handled. First, the chloride content at the rebars levels depends on a diffusion law in concrete. The law which is the most often used is the Fick's law which neglects reactions between chlorides and constituents such as tricalcium aluminate. However, experimentations have shown that Fick's law is very often applicable. This investigation determines in which cases the chemical reactions may be neglected in the diffusion laws. 
El segundo punto hace referencia a la existencia de una concentración crítica de cloruro. Más allá de ésta los productos de recubrimiento de los aceros dejan de tener las mismas características de estanquidad que en el caso de un hormigón no contaminado. Se trata pues de demostrar que para cantidades pequeñas de cloruro, los productos de recubrimiento tienen una microestructura diferente de aquella que corresponde a altos contenidos de cloruro.

\section{LA DIFUSION DE LOS CLORUROS EN EL HORMIGON}

\subsection{Elementos del problema}

La difusión de un ion disuelto en el agua contenida en los poros del hormigón está descrita de forma general por la ley de Fick. Sin embargo, con todo rigor, esta ley no se aplica más que a casos sencillos que corresponden a una penetración, sin reacción química, de un elemento en un sólido homogéneo.

Por ello, conviene evaluar la diferencia entre la difusividad (coeficiente de difusión) aparente, obtenida aplicando la ley de Fick al hormigón, y la difusión real del ion en el agua de los poros bajo la acción de un gradiente de concentración. En el caso de los cloruros, la difusividad aparente en los hormigones es del orden de $10^{-10}$ a $10^{-7} \mathrm{~cm}^{2} / \mathrm{s}$.

\subsection{Principios para la modelizacion}

Se da por supuesto que el agua en los poros del hormigón está a temperatura constante. No experimenta ni evaporación, ni heladas, ni está sometida a presión mecánica alguna.

La difusión del ion puede producirse en el volumen del líquido intersticial o en la superficie de las paredes de los poros.

El modelo de difusión que consideramos aquí admite la existencia de "lugares" donde se puede encontrar el ion. Se trata, o bien de las distintas posiciones de los iones en la superficie de las paredes de los poros, o de los pequeños volúmenes cuya dimensión corresponde a la media del recorrido libre de los iones en el líquido intersticial (figura 1, epígrafe 2.3.). Así, las "paredes" del "lugar" son del orden de $10^{-10}$ a $10^{-9} \mathrm{~m}$ en la pared del poro y de $10^{-8}$ a $10^{-7} \mathrm{~m}$ en el poro.

En ciertos lugares, un ion puede quedar atrapado, es decir, que su difusión queda retardada o interrumpida. Este cepo
The second item deals with the existence of a critical chloride content, beyond which products covering steels have no more the same tightness properties as for a not polluted concrete. So, it deals with showing that for the lowest chloride contents, the covering products have a defined microstructure which is different from the microstructure corresponding to the highest chloride contents.

\section{CHLORIDE DIFFUSION IN CONCRETE}

\subsection{Background}

The diffusion of an ion dissolved in water located in concrete pores is generally described by the Fick's law. However, strictly speaking, this law is applicable only to simple cases corresponding to penetrations without any chemical reactions of an element in a solid body.

Therefore, it is convenient to assess the scatter between the apparent diffusion obtained by using Fick's law for concrete, and the real diffusion of the ion in the pore water under the action of a content gradient. For chlorides, the apparent diffusivity in concrete is ranging in the orders of $10^{-10}$ to $10^{-7} \mathrm{~cm}^{2} / \mathrm{s}$.

\subsection{Principles for modelizing}

The water in concrete pores is assumed to be at a constant temperature. It undergoes no mechanical loading, such as a pressure and neither evaporation or frost are to be taken into account.

The ion diffusion can occur in the bulk volume of the intersticial liquid and at the surfaces of the pore walls.

The diffusion model we consider here, assumes the existence of "sites" where the ion can be located. It deals either with the various positions of the ion at the surfaces of the pore walls, or with small volumes whose sizes correspond to the mean free path of the ion in the intersticial liquid (Figure 1). So, the "Sides" of such sites are in the orders of $10^{-10}$ to $10^{-9} \mathrm{~m}$ at pore walls and from $10^{-8}$ to $10^{-7} \mathrm{~m}$ in the intersticial liquid.

At some sites, an ion can be trapped, i.e. its diffusion is slackened or stopped. These traps correspond, for example, to elements which 


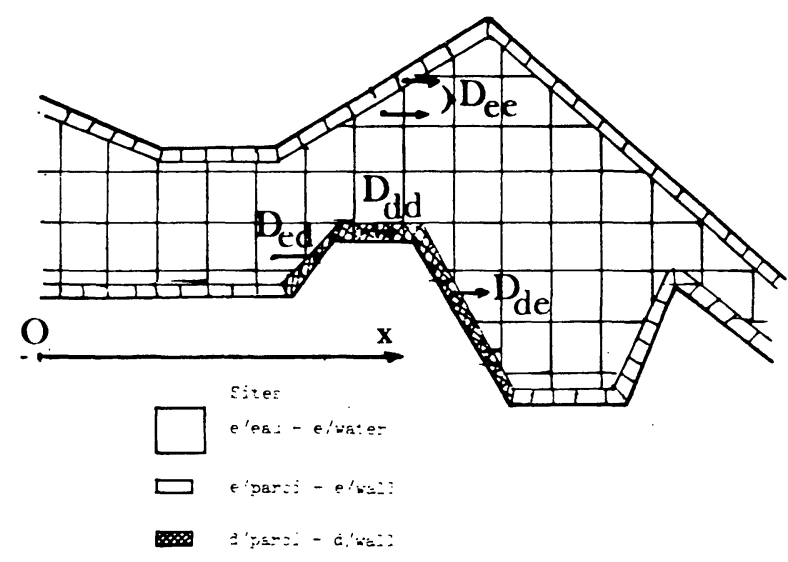

Fig. 1

corresponde, por ejemplo, a elementos que pueden reaccionar con el ion agresivo difusor.

En fin, aunque este modelo pueda aplicarse a una difusión en un espacio tridimensional, los cálculos se efectúan por una difusión unidireccional.

Entonces, la ley de Fick se escribe can react with the diffusing aggressive ion.

At last, even though this model is applicable in a three-dimension space, calculations are are crried out for a one-direction diffusion. Then, the Fick's law is si $x$ es la profundidad, $t$ el tiempo, $c$ la concentración y $j$ el flujo de materia:

$$
\frac{\partial c}{\partial t}=-\frac{\partial j}{\partial x}
$$

if $x$ is the depth, $t$ the time, $c$ the ion content and $j$ the flux

$$
j=-D \frac{\partial c}{\partial x}
$$

siendo $D$ la difusividad.

\subsection{Difusividad aparente}

La difusividad de un ion en el hormigón puede ser evaluada, mejorando la hipótesis de la ley de Fick.

El gradiente de concentración de iones agresivos, origen de la difusión, se debe a que el hormigón está en contacto con un medio (solución) acuosa cuyo contenido de este ion es mucho más elevado que la concentración correspondiente en el hormigón de origen (1).

Sea $n_{\mathrm{e}}$ el número de huecos (e) donde puede quedar el ion agresivo sin experimentar reacción alguna y $n_{d}$ el número de huecos defectuosos $(d)$ donde este ion puede quedar atrapado (cepos), las concentraciones respectivas de dichos sitios son:
$D$ being the diffusivity.

\subsection{Apparent diffusivity}

The diffusivity of an ion in concrete can be calculated by improving the Fick's law assumptions. The aggressive ion content gradient which initiates the diffusion is due to the fact that the concrete in in contact with an aqueous medium (solution) in which the ion content is higher than the corresponding content in the initial concrete (1).

Let $n_{e}$ be the number of sites (e) where the aggressive ion can be without undergoing any reaction and $n_{d}$ the number of "defective" sites (d) (traps) where the ion can be trapped; the respective concentrations of these sites are

$$
f_{\mathrm{e}}=\frac{n_{\mathrm{e}}}{n_{\mathrm{e}}+n_{\mathrm{d}}}
$$




$$
f_{\mathrm{d}}=\frac{n_{\mathrm{d}}}{n_{\mathrm{e}}+n_{\mathrm{d}}}
$$

Si la concentración (atómica) del ion en el agua de los poros es $c_{\mathrm{e}}$ y su concentración en los huecos (cepos) $c_{d}$, la concentración (atómica) total es:
If the (atomic) concentration of the ion in the pore water is $c_{e}$ and its content in defects (traps) is $c_{d}$, the total (atomic) concentration is

$$
c_{\mathrm{T}}=f_{\mathrm{e}} c_{\mathrm{e}}+f_{\mathrm{d}} c_{\mathrm{d}}
$$

El ion puede desplazarse de un lugar a otro. Las difusividades que corresponden a los diversos huecos son (Figura 1):

$D_{\text {ee }}$ para una difusión de un hueco no defectuoso (e) a otro.

$D_{\text {dd }}$ para una difusión de un hueco cepo $(d)$ a otro (pequeña magnitud).

$D_{\text {ed }}$ para una difusión de un hueco (e) a otro (d) y

$D_{\text {de }}$ para una difusión de un hueco cepo $(d)$ a un hueco no defectuoso (e).

La penetración se hace siguiendo un eje Ox; la abscisa $x$ crece con la profundidad de penetración. La generalización para un espacio tridimensional es fácil: se trata en general de sustituir derivadas (con relación a $x)$ por un gradiente o una divergencia.

De entre los $n_{\mathrm{e}}$ huecos normales, existen $\left(n_{\mathrm{e}} r_{\mathrm{e}}\right)$ huecos para los que el salto de difusión corresponde a $x$ creciente. Del mismo modo entre los $n$ lugares cepo, hay algunos $\left(n_{d} r_{d}\right)$ para los que el salto del ion corresponde $a x$ creciente.

Se puede obtener el flujo total de $J_{T}$ de difusión por el modelo de PARK, HONG y LEE, que de hecho corresponde a una difusión con el atrapado del hormigón en un metal, y que considera los distintos "pasos" del ion difusor de un lugar a otro:
The ion can move from one site to an other one. The diffusivities corresponding to the various sites are (Figure 1):

$D_{e}$ for a diffusion from a normal site (e) to an other site (e),

$D_{d d}$ for a diffusion from a trapping site (d) to an other site (d) (this value is very low),

$D_{e d}$ for a diffusion from a site (e) to a trap (d) and

$D_{d e}$ for a diffusion from a trapping site (d) to a normal site (e).

The penetration runs following the Ox axis direction, the abscissa $x$ increasing with the penetration depth. Generalizing for a three-dimension space is easy: it mainly deals with replacing derivative (versus $x$ ) by a gradient or a divergence.

Among the $n_{e}$ normal sites, there $n_{e} \cdot r_{e}$ sites for which the diffusion jumps correspond to increasing $x$. Correspondingly, among the $n_{d}$ sites, there are $n_{d} r_{d}$ sites for which the ion jump corresponds to increasing $x$.

The total diffusion flux can be obtained by the PARK-HONG-LEE model (2) which, in fact, correspond to a diffusion with trapping of hydrogen in a metal and which considers the various jumps of the ion diffusing from one site to an other one:

$$
J_{T}=-\left[A+B\left(1-c_{d}\right)+E c_{d}\right] \frac{\partial c_{e}}{\partial x}-\left[F+B c_{e}+E\left(1-c_{d}\right)\right] \frac{\partial c_{d}}{\partial x}
$$

con:

with

$$
\begin{aligned}
& A=f_{\mathrm{e}} r_{\mathrm{e}} D_{\mathrm{ee}} \\
& D=f_{\mathrm{d}} r_{\mathrm{d}} D_{\mathrm{de}}
\end{aligned}
$$

La difusividad aparente $\bar{D}$ queda definida por la relación:
The apparent diffusivity $\bar{D}$ is defined by the relationship 


$$
J_{\mathrm{T}}=-\bar{D} \frac{\partial c_{t}}{\partial x}=-\bar{D}\left[f_{\mathrm{e}} \frac{\partial c_{\mathrm{e}}}{\partial x}+f_{\mathrm{d}} \frac{\partial c_{\mathrm{d}}}{\partial x}\right]
$$

que da, teniendo en cuenta las relaciones (2) which gives, taking into account the relationships (2)

$$
\bar{D}=\frac{\left[r_{\mathrm{e}} D_{\mathrm{ee}}+\left(1-r_{\mathrm{e}}\right) D_{\mathrm{ed}}\right] f_{\mathrm{e}} \frac{\partial c_{\mathrm{e}}}{\partial x}+\left[r_{\mathrm{e}} D_{\mathrm{dd}}+\left(1-r_{\mathrm{d}}\right) D_{\mathrm{de}}\right] f_{\mathrm{d}} \frac{\partial c_{\mathrm{d}}}{\partial x}}{f_{\mathrm{e}} \frac{\partial c_{\mathrm{e}}}{\partial x}+f_{\mathrm{d}} \frac{\partial c_{\mathrm{d}}}{\partial x}}
$$

Las hipótesis complementarias siguientes simplifican la expresión de la difusividad aparente $\bar{D}$ :

a) No existen lugares-cepo a partir de los cuales el ion agresivo saltaría hacia una mayor penetración, sea $r_{\mathrm{d}}=0$. Esta hipótesis es compatible con la siguiente, aunque más general: la difusividad correspondiente a una migración de un cepo a otro es nula $\left(D_{\mathrm{dd}}=0\right)$.

b) La difusividad "a partir de un lugar no defectuoso" no depende del lugar donde el ion "llega" $\left(D_{\mathrm{ee}}=D_{\mathrm{ed}}\right)$.

La difusividad aparente es pues para una profundidad $x$,
The following supplementary assumptions simplify the relationship (4) defining the apparent diffusivity $\bar{D}$ :

a) There is no trapping site from which the aggressive ion jumps in the increasing depth direction, i.e. $r_{d}=0$. This assumption is compatible with the following one, while being more general: the diffusivity corresponding to jumps from a trap to an other one is zero $\left(D_{d d}=0\right)$.

b) The diffusivities corresponding to jumps starting from a normal site do not depend on the site where the ion arrives $\left(D_{\text {ee }}=D_{e d}\right)$.

Then, the apparent diffusivity, for a depth $x$, at time $t$ is

$$
\bar{D}=\frac{m D_{e e}+n D_{d e}}{m+n}
$$

con:

$$
\begin{array}{r}
\mid \text { with } \\
m=f_{\mathrm{e}} \frac{\partial c_{\mathrm{e}}}{\partial x} \\
\mid \begin{array}{l}
\text { and } \\
n=f_{d} \frac{\partial c_{d}}{\partial x}
\end{array}
\end{array}
$$

y

\subsection{Diferencia entre la difusividad aparente y la difusividad en ausencia de "cepos"'}

Según la relación (5), la diferencia entre la difusividad aparente y la difusividad en ausencia de cepos es:

\subsection{Difference between the apparent diffusivity and the diffusivity in the absence of trapping}

According to the relationship (5), the difference between the apparent diffusivity and the diffusivity in the absence of trapping is

$$
\bar{D}-D_{\mathrm{ee}}=\frac{n}{m+n}\left(D_{\mathrm{de}}-D_{\mathrm{ee}}\right)
$$

Esta diferencia no es apreciable en los casos siguientes:
This difference may be neglected in the following cases: 
a) $n=f_{d}\left(\partial c_{d} / \partial x\right)=0$ : el número de cepos no es apreciable $\left(f_{d}=0\right)$, o el gradiente de concentración de iones atrapados es nulo. El primer caso corresponde a una difusión sin cepo, mientras que la segunda condición puede corresponder a cepos ineficaces $\left(c_{d}=0\right)$ o a cepos saturados de iones.

b) $D_{\text {de }} \simeq D_{\text {ee }}$ : el cepo es muy poco eficaz ya que la difusividad del ion a partir de un cepo es casi igual a la difusividad a partir de un hueco normal.

c)

$$
\frac{m}{n} \gg 1
$$

sea

either

$$
f_{\mathrm{e}} \frac{\partial c_{e}}{\partial x} \gg f_{d} \frac{\partial c_{d}}{\partial x}
$$

○

$$
\begin{array}{c|c} 
& \text { or } \\
\frac{f_{d}}{f_{e}} \ll \frac{\frac{\partial c_{e}}{\partial x}}{\frac{\partial c_{d}}{\partial x}}
\end{array}
$$

Dado que $f_{\mathrm{d}} f_{\mathrm{e}}$, este caso corresponde por ejemplo a:

As $f_{d}<f_{\mathrm{e}}$, this case corresponds, for example, to

$$
\frac{\partial c_{e}}{\partial x} \gg \frac{\partial c_{d}}{\partial x}
$$

El gradiente de concentración de iones es mucho más bajo que el gradiente de concentración de iones difundidos sin haber sido atrapados.

En el caso de un ion en el hormigón, la difusividad aparente $\bar{D}$ es igual a la difusividad en el agua de los poros, sin atrapado, si al menos una de las siguientes condiciones se cumple:

A) El cemento no contiene elementos que puedan reaccionar con el ion difusor, ni siquiera atraparlo temporalmente. No es éste el caso de los cloruros.

B) Los poros del hormigón son bastante anchos, de modo que el número de cepos no es apreciable. En efecto, estos cepos corresponden a cuerpos sólidos, que se encuentran alrededor de los poros y que reaccionan con el ion difusor.

C) El cepo para el ion difusor es poco eficaz.
The content gradient is far lower than content gradient of ions which would have diffused without being trapped.

In the case of an ion concrete, the apparent diffusivity $\bar{D}$ is equal to its diffusivity in pore water, without trapping, when at least one of the following conditions is met.

A) The cement contains no element which can neither react with the diffusing ion or even temporarily trap it. This is not the case of chlorides.

B) The concrete pores are wide enough, so that the numer of traps may be neglected. These traps indeeed correspond to solid bodies which are around the pores and which react with the diffusing ion.

C) The trapping of the diffusing ion is not very efficient. 


\section{LOS PRODUCTOS DE CORROSION}

\subsection{Planteamiento del problema}

Se admite frecuentemente, que los aceros se corroen dentro del hormigón a una velocidad notable, si el contenido de cloruro en contacto con los aceros sobrepasa un umbral que depende del $\mathrm{pH}$ (2). Esta regla que fue obtenida experimentalmente, no indica si, para cantidades pequeñas de cloruros, la corrosión metálica se produce a una velocidad no apreciable o si, por el contrario, los productos de corrosión de los aceros son diferentes de aquellos que corresponden a cantidades grandes.

En otros términos, se plantea saber si el contenido-umbral de cloruro corresponde o no a una diferencia de naturaleza, o sea de estanquidad, de los productos de corrosión sobre el acero.

\subsection{Principios de la experimentación}

El proceso de corrosión del metal se compone de varias reacciones elementales. En la primera fase se producen dos reacciones simultáneamente en sitios diferentes: por una parte la disolución del metal y por otra parte una reacción catódica como la formación de iones hidroxilos $\left(\mathrm{OH}^{-}\right)$. En segunda fase, los iones metálicos en medio acuoso reaccionan con los aniones que allí se encuentran, para formar un producto capaz de recubrir el metal: se trata de la pasivación. Este estudio se centra en la naturaleza del producto de recubrimiento, no ocupándose de la primera fase que incluye las reacciones de disolución y las reacciones catódicas.

La experimentación (3) se centra en las soluciones con contenido de iones que reaccionan para formar productos de recubrimiento, es decir soluciones acuosas que contienen iones $\mathrm{Fe}^{++}, \mathrm{Cl}^{-}$y $\mathrm{OH}^{-}$. El pH de estas soluciones es bastante elevado $y$ corresponde a hormigones sanos $(\mathrm{pH} \simeq 12) 0$ carbonatados $(\mathrm{pH} \simeq 10$ ) o incluso a aguas que circulan en un hormigón muy poroso $(\mathrm{pH} \simeq 7$ ).

Dos tipos de experimentos han sido efectuados en paralelo: la primer serie es de tipo electroquímico y trata de estudiar la estabilidad o la evolución del pH de una solución $\left(\mathrm{Fe}^{++}, \mathrm{Cl}^{-}, \mathrm{OH}^{-}\right)$con el paso del tiempo.

La segunda serie de experimentos utiliza la espectrometria Mössbauer para determinar la estructura de los productos de corrosión.

\section{THE CORROSION PRODUCTS}

\subsection{Background}

It is often agreed that in concrete, steels are corroded with a noticeable rate if the chloride content in the concrete at the steels levels is higher than a threshold which depends on the $\mathrm{pH}$ (2). This rule was obtained experimentally. It does not say if for the lowest chloride contents the metal corrosion is occurring, but with a negligible rate, or if, on the contrary, for these lowest contents, the corrosion products are different from the products which correspond to higher chloride contents.

In other words, pending question is to know if the chloride content threshold correspond or not to a difference in the nature, therefore in the tightness, of the corrosion en steel.

\subsection{Principles of the experimentation}

The metal corrosion process includes several elementary reactions. In a first step, the two reactions which occur simultaneously at different places, are the metal dissolution and a cathodic reaction, such as hydroxyl ions $\left(\mathrm{OH}^{-}\right)$formation.

In a second stage, the metallic ions dissolved in the aqueous medium react with anions which are present ad yield a product which can cover the metal (passivation). This study is focussed on the nature of the covering products. The first stage which includes dissolution and cathodic reactions will be neglected.

The experimentation (3) concerns solutions containing the ions which react and yield the covering products, i.e. solutions containing $\mathrm{Fe}^{++}, \mathrm{Cl}^{-}$and $\mathrm{OH}^{-}$. These solutions are of high enough $\mathrm{pH}$ and correspond to either sound concrete $(p H \geq 12)$ or carbonated concrete ( $\mathrm{pH} \geq 10$ or even to waters circulating in a very porous concrete $(\mathrm{pH} \geq 7)$.

The experiments are of two different types. A first series of experiments are electrochemical. It deals with studying the $\mathrm{pH}$ stability or evolution of a $\left(\mathrm{Fe}^{++}, \mathrm{Cl}^{-}, \mathrm{OH}^{-}\right)$solution versus time.

The second series of experiments uses Mössbauer spectrocopy for determining the corrosion products structures. 


\subsection{Evolución de las soluciones} $\left(\mathrm{Fe}^{++}, \mathrm{Cl}, \mathrm{OH}^{-}\right)$

Las diferentes soluciones estudiadas son mezclas de cloruros ferrosos $\mathrm{FeCl}_{2}$ y de hidróxido de sodio $\mathrm{NaOH}$.

En el estudio global, la relación $|\mathrm{Cl}| / \mid \mathrm{OH}$ varía de 0,75 a 8 de manera que el $\mathrm{pH}$ inicial de estas soluciones varia de unos 12 a 5,5. Pero únicamente las soluciones cuyo $\mathrm{pH}$ inicial es superior a 7 son tomadas en consideración, sea $\left|\mathrm{Cl}^{-}\right| /\left|\mathrm{OH}^{-}\right| \leq 4$.

La figura 2 da la variación del $\mathrm{pH}$ de las soluciones $\left(\mathrm{Fe}^{++}, \mathrm{Cl}^{\circ}, \mathrm{OH}^{-}\right)$a $25^{\circ} \mathrm{C}$ en función del tiempo. Resulta que si la relación $\left|\mathrm{Cl}^{-}\right| /\left|\mathrm{OH}^{-}\right|<1$, el $\mathrm{pH}$ de la solución es estable, mientras que si $\left|\mathrm{Cl}^{-}\right| /\left|\mathrm{OH}^{-}\right| \geq 1$, el $\mathrm{pH}$ disminuye en las primeras horas ya que se produce una reacción.

\subsection{Naturaleza de los productos formados}

La espectrometría Mössbauer permite determinar la naturaleza de los productos formados por evolución de las soluciones $\left(\mathrm{Fe}^{++}, \mathrm{Cl}^{-}, \mathrm{OH}^{-}\right)(4)$.

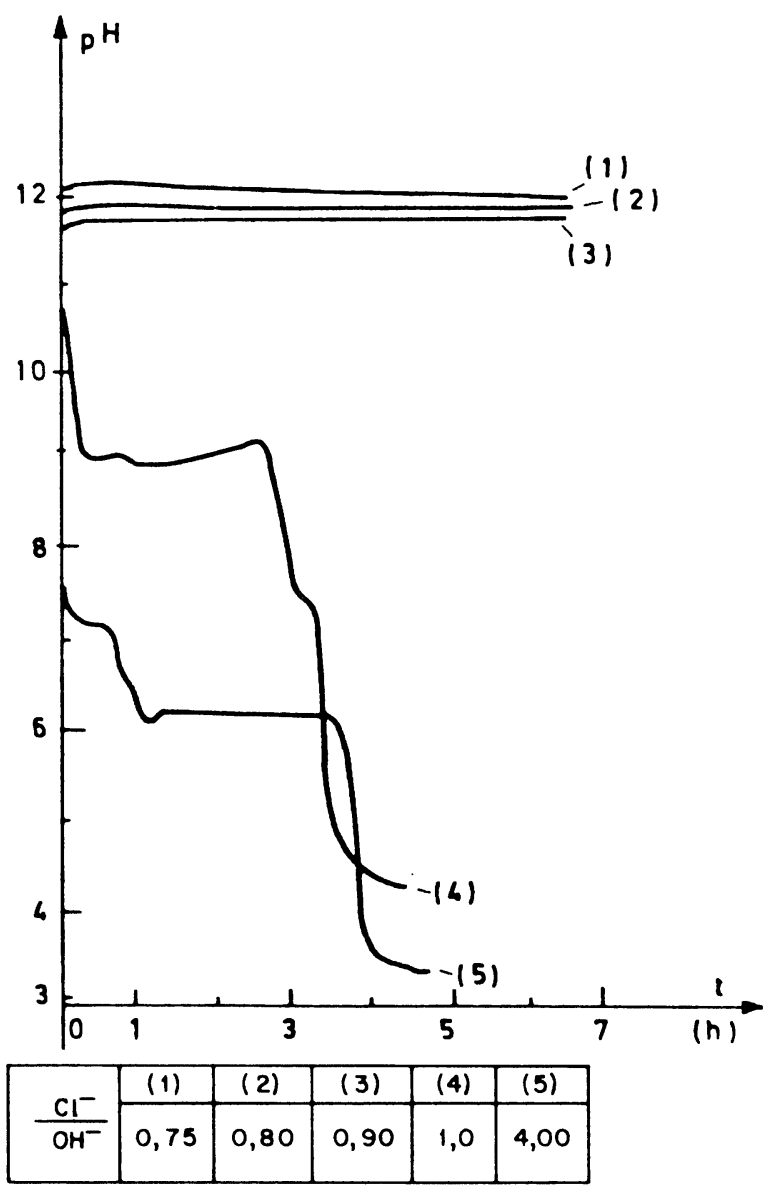

Fig. 2

\subsection{Evolution of the $\left(\mathrm{Fe}^{++}, \mathrm{Cl}, \mathrm{OH}\right)$ solutions}

The various solutions which have been studied were mixtures of ferrous chloride and sodium hydroxide $\mathrm{NaOH}$. In the whole investigation, the $[\mathrm{Cl}] /[\mathrm{OH}]$ ratio was ranging between 7.5 and 8.0, so that the initial pH of these solutions were ranging between about 12 to 5.5. But, only solutions having $\mathrm{pH}$ higher than 7 are considered her, i.e. $[\mathrm{Cl}] /[\mathrm{OH}] \leq 4$.

Figure 2 gives the $\left(\mathrm{Fe}^{++}, \mathrm{Cl}^{-}, \mathrm{OH}\right)$ solutions $\mathrm{pH}$ change versus time at $25^{\circ} \mathrm{C}$. It appears that if the $[\mathrm{Cl}] /\left[\mathrm{OH}^{-1}\right]$ ratio is lower than 1 , the solution $\mathrm{pH}$ is constant. On the contrary, if $[\mathrm{Cl}] /[\mathrm{OH}] \geq 1$, the $\mathrm{pH}$ decreases during the first hours, because a reaction is occurring.

\subsection{Nature of the products}

The Mössbauer spectroscopy makes it possible to determine the natures of the products yielded by the evolution of the $\left(\mathrm{Fe}^{++}, \mathrm{Cl}, \mathrm{OH}\right)$ solutions (4).
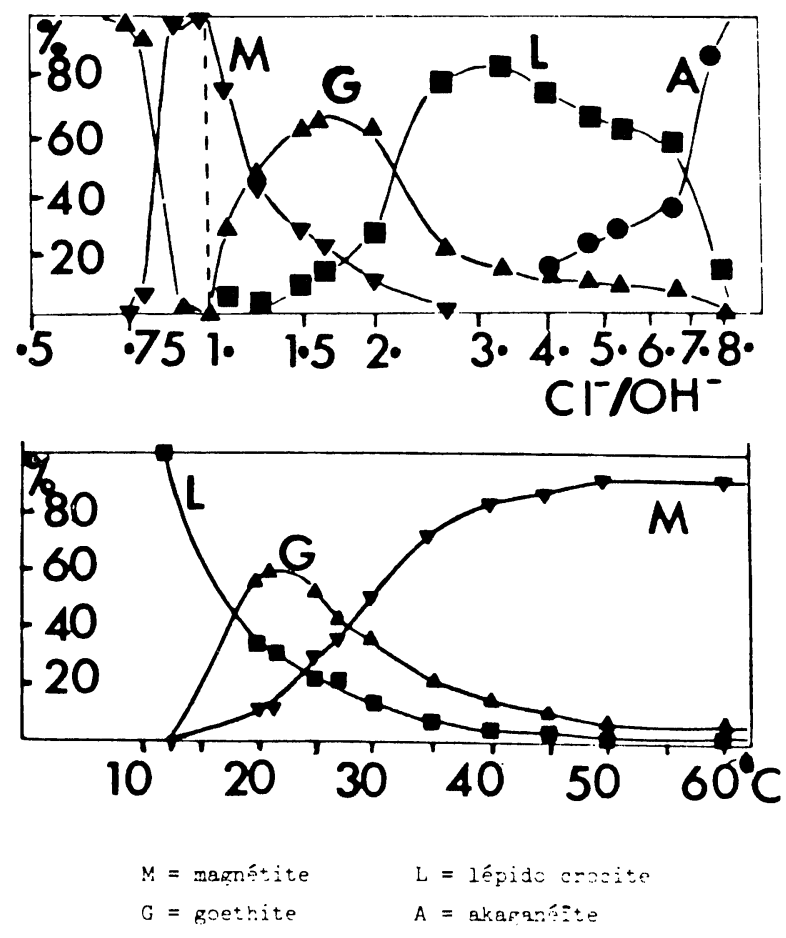

Fig. 3 
La figura 3 da las proporciones de los productos formados a $25^{\circ} \mathrm{C}$ cuando la relación $\left|\mathrm{Cl}^{-}\right| /\left|\mathrm{OH}^{-}\right|<1$, no aparece más que goetita $(\alpha$-FeOOH $)$ y magnetita. $\mathrm{Si}\left|\mathrm{Cl}^{-}\right| /\left|\mathrm{OH}^{-1}\right|>1$, se forma lepidocrocita $(\gamma+8 \mathrm{FeOOH}, \mathrm{FeOCI})$, goetita y, para $1<|\mathrm{Cl}| /|\mathrm{OH}| \leq 2,5$, magnetita. Las proporciones quedan modificadas cuando la temperatura de la solución varía, pero la existencia de una concentración umbral para los cloruros subsiste. Este resultado se explica según el modelo siguiente, que ha sido confirmado por la espectrometría Mössbauer.

Para pequeñas cantidades de cloruro, el producto inicial que se forma a partir de la solución $\left(\mathrm{Fe}^{++}, \mathrm{Cl}^{-}, \mathrm{OH}^{-}\right)$es el hidróxido ferroso $\mathrm{Fe}(\mathrm{OH})_{2}$ que no puede transformarse en lepidocrocita. Cuando el contenido de cloruro es bastante elevado, se forma un compuesto intermedio que es el óxido verde I [2 $\left.\mathrm{Fe}(\mathrm{OH})_{2}, \mathrm{FeOHCl}, \mathrm{Fe}(\mathrm{OH})_{2} \mathrm{Cl}\right]$ que se transforma en lepidocrocita mientras que la goetita y la magnetita se forman a partir de la solución $\left(\mathrm{Fe}^{++}, \mathrm{Cl}^{-}, \mathrm{OH}^{-}\right)$. Cuando el contenido de cloruro es suficientemente elevado, el hidróxido de partida (hidróxido II) contiene cloro $2 \mathrm{Fe}(\mathrm{OH})_{2}$, FeOHCll y se transforma en un compuesto intermedio, el óxido verde I $\mid 2 \mathrm{Fe}(\mathrm{OH})_{2}, \mathrm{FeOHCl}, \mathrm{Fe}(\mathrm{OH})_{2} \mathrm{Cl}$ según la reacción:
Figure 3 gives the percentages of the products precipitated at $25^{\circ} \mathrm{C}$. When the $[\mathrm{Cl}] /[\mathrm{OH}]$ ratio is lower than 1 , only goethite $(\alpha-\mathrm{FeOOH})$ and magnetite appear. If $[\mathrm{Cl}] /[\mathrm{OH}]>1$, the formed products are lepidocrocite $(\gamma-[8 \mathrm{FeOOH}, \mathrm{FeOCl}])$, geothite and, for $1<[\mathrm{Cl}] /[\mathrm{OH}]<2.5$, magnetite. These percentages are modified when the solution temperature changes, but the existence of a chloride content threshold remains. This result is explained by the following model which has been confirmed by Mössbauer spectrometry.

For the lowest chloride contents, the initial product due to the $\left(\mathrm{Fe}^{++}, \mathrm{Cl}^{-}, \mathrm{OH}^{-}\right)$solution evolution is ferrous hydroxide $\left[\mathrm{Fe}(\mathrm{OH})_{2}\right]$ which cannot change into lepidocrocite. When the chloride content is high enough, the initial hydroxide (hydroxide-II) contains chlorine [2 $\mathrm{Fe}(\mathrm{OH})_{2}, \mathrm{FeOHCl}$ and changes itself into an intermediate compound, the green-rust-I [2 $\mathrm{Fe}(\mathrm{OH})_{2}, \mathrm{FeOHCl}, \mathrm{Fe}(\mathrm{OH})_{2} \mathrm{Cl}$ ] according to the reaction

$$
\begin{aligned}
& 2\left|2 \mathrm{Fe}(\mathrm{OH})_{2}+\mathrm{FeOHCl}\right| \rightarrow\left|2 \mathrm{Fe}(\mathrm{OH})_{2}, \mathrm{FeOHCl}, \mathrm{Fe}(\mathrm{OH})_{2} \mathrm{Cl}\right|+\mathrm{Fe}(\mathrm{OH})_{2}+\mathrm{FeOH} \\
& \text { Hidróxido II Oxido verde I Hidróxido I } \\
& \text { hydroxide-ll green-rust-l hydroxide-l }
\end{aligned}
$$

El óxido verde I forma entonces lepidocrocita $|8 \mathrm{FeOOH}, \mathrm{FeOCI}|$ que asimismo contiene cloro. Por su parte, la goetita y la magnetita se forman de nuevo a partir del hidróxido I y de los iones $\mathrm{FeOH}^{+}$de la solución, obtenidos por la reacción anteriormente citada.

Por fin debemos señalar que la magnetita formada no corresponde a la fórmula estequiométrica $\mathrm{Fe}_{3} \mathrm{O}_{4}$. En los espectros Mössbauer se observa que la magnetita obtenida presenta lagunas de hierro en la sub red tetraédrica y octaédrica de la espinela. En particular, cuando $\left|\mathrm{Cl}^{-}\right| /\left|\mathrm{OH}^{-}\right|<1$ sólo quedan afectados los huecos octaédricos, mientras que cuando $\left|\mathrm{Cl}^{-}\right| /\left|\mathrm{OH}^{-}\right|>1$, los huecos tetraédricos pueden igualmente quedar vacíos, lo que prueba que la magnetita experimenta una protonización, es decir que los iones $\mathrm{O}^{2-}$ son reemplazados por los iones hidróxidos $\mathrm{OH}^{-}$. Así pues, es probable que la magnetita esté formada a partir de los iones $\mathrm{FeOH}^{+}$de la solución, dejando que se forme la goetita a partir del hidróxido I $\mathrm{Fe}(\mathrm{OH})_{2}$, y la lepidocrocita a partir del hidróxido II $2 \mathrm{Fe}(\mathrm{OH})_{2} \mathrm{FeOCl}$ vía óxido verde I.
Then, the green-rust-I gives lepidocrocite [O-FeOOH, FeOCl] which contains chlorine. On the other hand, goethite and magnetite are formed agin, starting from hydroxide-l and $\mathrm{FeOH}^{+}$ions obtained in the solution according to the above reaction.

At last, we have to notice that the formed magnetite does not correspond to the stoichiometric formula $\mathrm{Fe}_{3} \mathrm{O}_{4}$. In the Mössbauer spectra, it is observed that the obtained magnetite has iron vacancies in the tetrahedral and octahedral sublattices of the spinelle. Particularly, when the ratio $[\mathrm{Cl}] /[\mathrm{OH}]<1$, only the octahedral sites are concerned and when the above ratio is higher than 1 the tetrahedral sites can also be empty. This proves that magnetite undergoes protonization, i.e. $\mathrm{O}^{2-}$ ions ions are replaced by hydroxyl ions $\mathrm{OH}$. So, magnetite is very likely formed by the $\mathrm{FeOH}^{+}$ions in the solution, while goethite is formed starting from hydroxide-l, $\mathrm{Fe}(\mathrm{OH})_{2}$, and lepidocrocite from hydroxide-ll, $2 \mathrm{Fe}(\mathrm{OH})_{2} \mathrm{FeOCl}$, via the green-rust-l. 


\section{APLICACIONES}

\subsection{Contenido de cloruro a nivel de las armaduras}

El contenido de cloruro en el hormigón a nivel de las armaduras depende de la difusividad del ion y de la geometría del sólido. La difusividad depende de la naturaleza del cemento y de la compacidad del hormigón. La geometría que se ha de considerar es la concerniente al espesor del recubrimiento de hormigón sobre las armaduras y a la microfisuración del hormigón.

Así, en otros términos, la ley de Fick permite calcular el contenido de cloruro a una profundidad dada si se conoce la difusividad y también las condiciones límites geométricas. Pero los resultados de los cálculos fundados en la ley de Fick dejarían de ser válidos si el contenido de aluminato tricálcico del cemento es muy elevado y si los poros de éste son muy pequeños. En la práctica, son poco frecuentes los casos en que falla la ley de Fick.

\subsection{Naturaleza de los productos de corrosión: nivel de contenido en cloro}

La espectrometría Mössbauer permite identificar los componentes de los productos de corrosión. De esta forma se ha demostrado que si los iones de partida son los mismos: $\mathrm{Fe}^{++}, \mathrm{Cl}^{-}$y $\mathrm{OH}^{-}$, la naturaleza final de los productos de corrosión varía en función de diversos factores como la temperatura, pero, sobre todo, el contenido de cloruro. En particular, la existencia de un hidróxido ferroso con contenido de cloro en proporción más alta que en la situación umbral crítica, tiene como resultado último la forma de lepido cloro crocita, sirviendo como intermediario el óxido verde I.

Los medios utilizados en estas experimentaciones corresponden a hormigones sanos o alterados por la carbonatación ( $\mathrm{pH}=9$ ) o incluso por ácidos.

Así, este estudio nos muestra que los productos de corrosión del hierro en medio clorado cambian bruscamente de naturaleza si el contenido de cloruros sobrepasa cierto umbral, aqui: $|\mathrm{Cl}|>|\mathrm{OH}|$.

Este umbral es del mismo orden de magnitud que el observado empíricamente. Además, la regla empírica de corrosión $|\mathrm{Cl}|>0,6\left|\mathrm{OH}^{-}\right|$ permite un margen de seguridad para evitar la corrosión por cloruros.

\section{APPLICATIONS}

\subsection{Chloride content near reinforcements}

The chloride content in concrete, at the level of reinforcements, depends on the ion diffusivity and on the geometry of the solid body. The diffusivity depends on the cement nature and on the concrete compactness. The geometry which is to be considered is the concrete cover thickness upon the reinforcements as well as the concrete microcracking.

So, in other words, the Fick's law makes it possible to compute the chloride content at a given depth, if the diffusivity is known and if the boundary geometry conditions are also known. But the results of these computations would not be valid anymore if the cement contains a very high tricalcium aluminate content and if its pores are very small. Practically, the cases when the Fick's law fails are not frequent.

\subsection{Nature of the corrosion products. Chloride content threshold}

The Mössbauer spectrometry makes it possible to identify the components of the corrosion products. So, it has been shown that even if the initial ions are the same, $\mathrm{Fe}^{++}, \mathrm{Cl}^{-}$and $\mathrm{OH}$, the nature of the final products changes in function of various parameters, such as temperature, and chiefly in function of the chloride content. In particular, the existence of a ferrous hydroxide which contains chlorine at a rate higher than a critical threshold, results in the final formation of lepidocrocite via greenrust-l.

The media used in the experimentations correspond either to sound concretes, or to concretes deteriorated by carbonation $(\mathrm{pH}=9)$ or even deteriorated by acids.

So, this investigation has shown that the nature of the iron corrosion products in a chlorinated medium sharply changes if the chloride content is higher than a certain threshold: here, $\left[\mathrm{Cl}^{-}\right]>[\mathrm{OH}]$.

This threshold is of the same order of magnitude as the threshold which has been empirically observed. Moreover, the empirical corrosion rule, $[\mathrm{Cl}]>0,6[\mathrm{OH}]$, gives a safety margin for preventing the iron corrosion by chlorides. 


\section{CONCLUSIONES}

De este estudio se pueden sacar conclusiones que conciernen a la previsión de la corrosión de aceros en hormigones situados en medios clorados.

Los productos que se forman en las armaduras por las reacciones de corrosión, son de naturalezas distintas según que el contenido de cloruro en el hormigón sea inferior o superior a cierto valor-umbral. En el caso en que el líquido que rodea al acero sea de gran volumen, esta concentración umbral es igual a $\left|\mathrm{Cl}^{-}\right|=\left|\mathrm{OH}^{-}\right|$. Es probable que el valor de este umbral quede ligeramente modificado por la presencia de poros en el hormigón.

Cuando la concentración de cloruro supera este umbral, los aceros no quedan protegidos de forma eficaz por los productos de recubrimiento, ya que la corrosión es relativamente importante. En este estudio, los resultados obtenidos a través de experiencias de electroquímica y espectroscopía Mössbauer confirman las reglas empíricas comunmente admitidas.

Para prever el instante en que la corrosión empieza a ser importante, basta conocer la difusividad $D$ de la ley (de Fick) de difusión de los cloruros en el hormigón, así como los parámetros geométricos tales como el espesor de recubrimiento. Este estudio demuestra, por medio de cálculos que la aplicación de la ley de Fick utilizando un coeficiente $D$ constante es válida para la mayoría de los casos. Las excepciones atañen a los cementos con alto contenido de aluminato tricálcico, en un hormigón con poca porosidad (o microporosidad).

\section{CONCLUSIONS}

The conclusions which can be drawn from this investigation, deal with forecasting the steel corrosion in a concrete put in an environment containing chlorides.

The products formed on reinforcing steels, due to corrosion reactions, are of various natures, depending on the chloride in concrete, as compared with a threshold content. In the case when the liquid surrounding steel has a large volume, this threshold is equal to $\left[\mathrm{Cl}^{-}\right]=\left[\mathrm{OH}^{-}\right]$. The real value of this threshold is likely slightly modified by the presence of the concrete pores.

When the chloride content is higher than the threshold, steels are not efficiently protected by the covering products: corrosion is of a noticeable importance. So, the results obtained in this investigation confirm the empirical rules which are usually agreed.

For forecasting the time from which the steel corrosion is of importance, it is sufficient to know the diffusivity $D$ to be used in the Fick's law of chloride diffusion in concrete, as well as geometrical parameters, such as the concrete cover thickness. This study has shown, by means of calculations, that applying Fick's law with a constant diffusivity is valid in most cases, when one may neglect the effects of pressure, evaporation and frost of the concrete water. The exceptions for the Fick's law validity concern cements with a high tricalcium aluminate concrete in a concrete with small porosity (or microporosity).

\section{REFERENCIAS}

(1) C. N. PARK, G. W. HONG, JAI YOUNG LEE: Troisième Congrès International Hydrog̀ne et Matériau, París 1982, vol. 2 (E9) p. 509-514.

(2) D. A. HAUSMANN: Materials Protection. Nov. 1967, p. 19-22.

(3) J. M. R. GENIN, D. RESEL, Ph. BAUER, A. OLANE and A. BERAL: Proc. symposium of Electrochemical Methods for Corrosion Research (Toulouse) July 1985.

(4) J. M. R. GENIN, Ph. BAUER, A. OLANE and D. RESEL: Journ. Hyperfine interaction, Proc. Int. Conf. of Applications of Mössbauer Effect (Leuven) Sept. 1985. 